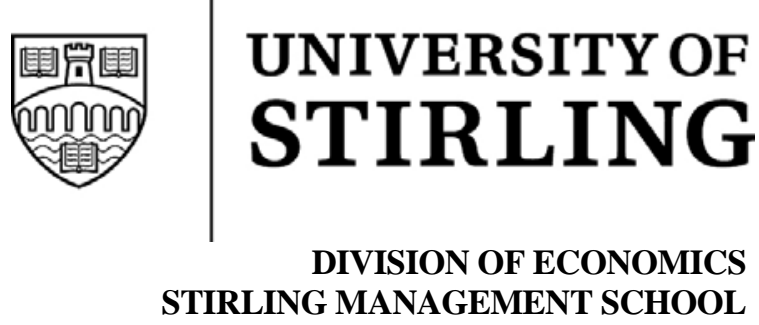

\title{
Above and beyond the call. \\ Long-term real earnings effects of British male military conscription during WWII and the post-war years
}

Robert A. Hart

Stirling Economics Discussion Paper 2009-09

April 2009

Online at http://www.economics.stir.ac.uk 


\title{
Above and beyond the call. Long-term real earnings effects of British male military conscription during WWII and the post-war years
}

\author{
Robert A. Hart \\ Department of Economics \\ University of Stirling and IZA
}

April, 2009

\begin{abstract}
This paper adds to the literature on the relationship between military service and long-term real earnings. Based on a regression discontinuity design it compares the earnings of age cohorts containing British men who were required to undertake post-war National Service with later cohorts who were exempt. It also compares age cohorts containing men who were conscripted into military service during the first half of WWII and those with later spells of conscription. It argues that, in general, we should not expect large long-term real earnings differences between conscript and non-conscript cohorts since important elements of the former received military training and experience of direct value in the civilian jobs market. In the case of call-up during WWII there is even more reason to expect that there was no major disadvantages to those conscripted. This occurred largely because their pre-military job status was preserved due to the employment of substitute women workers who acted as a temporary employment buffer thereby protecting serving men's positions on the jobs hierarchy.
\end{abstract}

JEL Classification: J24, J31, N44

Key Words: National Service, WWII conscription, long-term real earnings, regression discontinuity design

Acknowledgements: Research was funded by ESRC Grant RES-000-22-2899. I am especially grateful to David French for invaluable guidance on historical detail and interpretation. Elizabeth Roberts provided first-class research assistance. I would also like to thank Sascha Becker, Paul Devereux and George Peden for useful advice. I retain full responsibility for remaining errors. 


\section{Introduction}

Existing studies into the effects of male military service on long-term earnings have generally concluded that it is associated with relatively deleterious outcomes. Angrist (1990) finds that white U.S. Vietnam war veterans received 15\% lower earnings than comparable non-veterans. Angrist and Krueger (1994) find that U.S. WWII veterans earned no more than comparable non-veterans and, in fact, might have earned more if they had not experienced military service. Imbens and van der Klaauw (1995) find that peacetime conscription in the Netherlands has resulted in 5\% lower earnings among conscripts than other members of their birth cohorts. Buonanno (2007) finds that British males who served post-war National Service earned between $4 \%$ and $6 \%$ less than the cohorts that immediately followed. This paper compares and contrasts the long-term earnings effects resulting from British conscription during WW11 and during the postwar era. Its central hypothesis is that we should not expect conscription to produce serious long term relative disadvantages in the civilian labour market.

The last period of male conscription into the British armed forces started in late 1939 and continued until the end of 1960 . With the exception of certain categories of males working in essential war occupations and industries, all able-bodied young men within specified age ranges were eligible for call-up. Apart from the relative probabilities of being engaged in active service, there are clear distinctions between those who were called-up during WWII and those called-up to post-war National Service. The former served for an expected duration of 4 years, ${ }^{1}$ more than double that of the latter. In fact,

1 If we assume that, on average, those posted into the armed forces in 1943, 1944 and 1945 (to June) served 2 years - not unreasonable given immediate post-war service 
$61 \%$ of those posted into the armed forces during WWII were called up between September 1939 and the end of 1941 and they served for an expected period of over 5 years. Second, those conscripted during the early years of WWII consisted largely of men between the ages of 18 and 35 . In contrast, post-war conscription was far more narrowly confined, mainly to 18 to 20 year olds. The main consequences of these divergent age ranges were twofold. First, pre-conscription, a 'typical' WWII recruit would have accumulated significantly more civilian work experience than his post-war equivalent. Second, numbers and age ranges of the early WWII conscripts, combined with the growth of war supply industries, demanded that radical solutions were required in order to meet the critical labour supply shortages.

The paper makes a general and a specific claim about the long-run returns to conscription. In general, it is argued that we should not expect major long-term real earnings disadvantages for age cohorts experiencing a period of conscription compared to subsequent cohorts who were exempt. Essentially, I say more on the central hypothesis of Angrist (1990) which holds that those who served in the military "earn less because their military experience is only a partial substitute for the civilian labor market experience lost while in the armed forces". For many conscripts, military service gave rise to highly transferable skills within the civilian labour market. For a sub-set of these, returns in post-military life resulting directly from conscription would almost certainly have been greater than those accruing in civilian life if no conscription had occurred. The specific claim is that early WWII conscripts had an especially reduced cost disadvantage.

lengths and that January, 1946 marked the modal demobilisation time for earlier postings - then the weighted mean length of wartime service is 3.9 years. 
One important reason is that many were replaced by women workers who, in effect, acted as a temporary employment buffer for the duration of the war. In effect, the buffer served to preserve men's relative positions in the jobs hierarchy on their return from war service. Moreover, the ability of conscripted males to regain their previous civilian jobs or generally to replace women in essential industries was backed both by legislation and by the attitudes of politicians, employers and union leaders.

Based on regression discontinuity designs, I examine two questions. First, how did long-term real earnings of post-war National Service conscripts compare with real earning of later cohorts who were completely exempt from compulsory state service? Second, how did long-term real earnings of early WWII conscripts compare to the real earnings of the conscripts that followed?

\section{Conscription to the Armed Services between September 1939 and December 1960}

Following the outbreak of war, the National Service (Armed Forces) Act of September 1939 imposed liability for military service on men aged between 18 and 41 . The upper bound age limit was extended to 51 years under the National Service (No. 2) Act of December 1941. Certain categories of worker were exempt from war service due to the essential nature of their work. ${ }^{2}$ In addition, men could have their call-up deferred for reasons of severe personal hardship. ${ }^{3}$ The numbers of men registered under the Acts

\footnotetext{
${ }^{2}$ Exemptions included the legal profession, accountancy, banking and insurance, trade union officials, the merchant navy, mining, food trades, agriculture, utilities (gas/ water/electricity industries), truck and bus drivers, engineers, industrial doctors, railway guards/shunters/porters.

${ }^{3}$ This could involve the long-term illness of a close relative, the dependency of an elderly parent, and the need to continue study in order to complete an apprenticeship or a higher education qualification.
} 
and the numbers posted to the armed forces throughout the war are shown in Table 1.

The year 1940 marked the peak of this activity, accounting for 35\% of wartime military postings. Wartime registration lasted from October 1939 to June 1945. Those called-up for military service were predominantly within the 18-35 age spectrum. Table 2 shows the net changes in the numbers of insured male workers (which exclude the armed forces) in the period 1942 to 1945 compared to 1937. Especially large reductions took place among male workers up to the age of 35 . Given that the data are adjusted for changes in the birth rates of these age cohorts ${ }^{4}$, it is safe to conclude that the vast bulk of the reductions were due to call-up to the armed forces. As shown in Table 3, numbers of men in the armed forces and civil defence grew by almost 4 million between mid-1939 and mid-1945.

Starting in the second half of 1945, the armed forces were reduced through a combination of demobilisation and lower rates of recruitment. Demobilisation was especially frenetic between October 1945 and October 1946, with a peak rate of over 100,000 men per week in January 1946 (MLNS, 1947, p. 360). Men under the age of 30 were still liable to registration and call-up, however. ${ }^{5}$ In 1947 and 1948, men were called up for service at age 18. The first cohort entered in January, 1947 and served for 2 years. This was gradually and monotonically reduced to 18 months by the call-up of the

${ }^{4}$ As explained in the Table notes, an allowance for the effect of changes in the birth rate on insured employment has been made. There were large fluctuations in male and female birth rates during WWI and the immediate years that followed.

${ }^{5}$ During 1945 and 1946 there were eight registration periods - in March, June, September and December of each year - covering men born between April 1927 and March 1929 (MLNS, 1947, p. 335). 
last cohort in December 1948. Under the National Service Act 1948, 'peacetime' conscription to the armed services was introduced in Great Britain, starting in January 1949. This was universally referred to as National Service. Up to October 1950, conscription lasted for a period of 18 months and then, in response to the Korean War, it was extended to 2 years. National Service ended on 31 December 1960 with the last man demobbed in May 1963. With few exceptions ${ }^{6}$, post-war conscription applied to all men aged 18 and over, the great majority of whom served within the narrow 18 to 20 year age band.

In effect, therefore, there was unbroken male military conscription between September 1939 and December 1960. Apart from the obvious factors related to the nature of WWII service and the relative length of wartime call-up, there is an important distinction between the two main episodes of conscription. As we have seen from Table 2, WWII conscription was dominated by men between the ages of 18 and 35. So, a large proportion had well established, pre-conscription, civilian work experience in adult employment. By contrast, post-war National Service was dominated by young men most of whom had little or no adult employment experience. ${ }^{7}$

\footnotetext{
${ }^{6}$ Those working in coal mining, farming and the merchant navy represented the bulk of exemptions.

${ }^{7}$ Actually, the position by the late 1950 s was slightly more complicated. Deferment to age 21 could be granted for those undertaking university degrees or apprenticeship programmes. Also, in line with wartime conscription, deferment could be granted on hardship grounds. As reported by Broad (2006), in both the war and post-war period about two-thirds of hardship applications were granted. Between 1947 to 1960 there were 93 thousand applications. As the required number of National Service recruits reduced in the late 1950s, there was a tendency to call-up previously deferred men rather than newly registered 18 year olds. In $1950,80 \%$ of conscripts were under the age of 20 compared to only $15 \%$ in 1958 .
} 


\section{The costs and benefits of military conscription}

(a) General issues relevant to all episodes of military conscription ${ }^{8}$

For a proportion of all conscripts, military service involves specialised training that is of little value in civilian working life. Perhaps the most obvious example is that of an infantryman. ${ }^{9}$ In such a case, military service creates a cost associated with a loss of general labour market experience. Additional costs relate to firm-specific human capital. There may have been an interruption to the acquisition of firm-specific training and/or a depreciation of specific skills already acquired prior as a result of military call-up. These costs may have been accentuated by the fact that military conscription is most prevalent among younger age ranges and so tends to be incurred during formative years of vocational work experience.

Another type of cost applies to a potentially broader group of conscripts. There is evidence that the return to civilian life may involve adjustment costs as young men attempt to make the transition between two very different environments. Hickman (2004, p.218) reports on a 1957 survey of 70 companies' experience of returning conscripts. Problems were reported of work motivation following spells in the services during which there was less demand on individuals' working time. Ferguson and Cunnison (1959) report on a study of 771 men who left school in Glasgow at the minimum age of 14 in 1947. Of these, 498 were called up for National Service (346 at age 18 and 152 at age 21

\footnotetext{
${ }^{8}$ I am indebted to David French for supplying me with helpful details presented in this sub-section.

${ }^{9}$ If it were the case that a representative infantryman possessed the desirable qualities itemised by Field Marshall Lord Wavell, then his specific military-oriented skills would be those of "a successful poacher, a cat-burglar and a gunman".
} 
in order for them to complete their apprenticeship training) with the remaining 273 rejected as unfit on medical grounds. The study makes comparisons of all 498 National Service men at age 17 and two years after demobilization. At age 17, $63 \%$ of those conscripted were in skilled work while at the later age this had dropped to $45 \%$. This tendency was more marked among those with 'below average scholastic ability', with respective figures of $60 \%$ and $37 \%$. For those not called-up, $40 \%$ were in skilled work at age 17 and $32 \%$ at an age comparable to those who had been two years at work postService. The interesting difference between the Service and non-Service groups is that men of 'good' or 'average' scholastic ability who were conscripted experienced drops in undertaking skilled work from $64 \%$ to $50 \%$ while their equivalents who were rejected for conscription showed no change, at a constant $41 \%$.

The potential benefits of call-up for later civilian work activities should not be underestimated, however. I concentrate on the army; equivalent and perhaps broader sets of examples apply to the air force and navy. Even within the combat armed sections of the army, significant numbers of soldiers undertook jobs that were of direct potential benefit to post-army livelihoods. Take the most combat intensive example of an infantry battalion. During WWII and the years that followed, about one-third of soldiers served in the infantry. In each battalion only about half of the 800 men fought with rifles and bayonets. By 1944, an infantry battalion included about 90 motor vehicles, ranging from motor cycles to 3 ton lorries, and needed drivers who were trained in basic maintenance. It included a pioneer platoon of about 30 men who were carpenters, plumbers, bricklayers. It also contained a signals platoon who were trained to operate quite complex radio and telephone equipment. In the remaining two-thirds of the army, the 
largest combat arms after the infantry were the Royal Artillery, Royal Armoured Corps, Royal Engineers and Royal Corps of Signals, the Royal Ordinance Corps, and the Royal Electrical and Mechanical Engineers. Unsurprisingly given their titles, all contained large numbers of soldiers classed as tradesmen who possessed a wide range of mechanical skills.

The types of practical know-how utilised above would have been improved during the period of conscription through on-the-job experience. Additionally, this process was aided and abetted through training offered directly by the army itself. Shortly after the outset of war, the army realised that it was recruiting insufficient numbers to fill its skill requirements. Moreover, it compounded this problem by employing manpower inefficiently, with mismatches between individual attributes and task allocations. Consequently, from 1942 all recruits were given intelligence and aptitude tests. Job descriptions were drawn up so that men with given aptitudes could be posted to the appropriate jobs. The transition from test score to job placement involved a period of job training (as much as 30 weeks, for example, for posting to the Royal Corps of Signals).

One of the earlier noted potential costs of post-war National Service was that the young age of conscripts may have involved particular serious losses of human capital acquisition at a critical early stage in the development of work experience. A priori, we might expect this to be especially the case for those post-war conscripts who had to commence military duty immediately following completion of their apprenticeships or university degrees. However, for many such qualified cases, conscription involved subsequent training and experience of value to later civilian life. Men with university degrees were directed along one of several routes. From the outset, they were earmarked 
as potential officers and attended a War Office Selection Board for a 3-day test to determine their potential leadership qualities. If they passed the test then, after 6 months training, they would spend 12-15 months as an officer, responsible for the lives of perhaps 30 men. Many who failed the test were posted to the Royal Army Education Corps where they had the opportunity in using university-acquired transferable skills in teaching soldiers numeracy and literacy. Men with science and engineering degrees were commissioned into one of the scientific corps where they could make direct use of their degrees. As for men with apprenticeship qualifications, the army and other services went to considerable lengths to make direct use of their acquired trade skills.

Of course, it is difficult to evaluate relative net gains and losses of age cohorts affected by conscription and those that later cohorts who were exempt. For at least onethird of infantrymen, army life must have resulted in unequivocal net losses of general human capital and, in some cases, depreciation of pre-army general and firm-specific capital. But others who were conscripted acquired training, trades and skills of direct value in civilian life. A sub-set of these almost certainly added value to their civilian worth that would have been greater than had they not been conscripted. This was probably especially true of those who, at a relatively very young age, were given leadership roles over quite large numbers of soldiers. In addition, the high levels of comradeship, loyalty, team effort and inter-group responsibility associated with military service offered considerable advantages to all classes of conscripts when they applied for jobs in post-army civilian life.

The foregoing arguments lead to two main conclusions. First, military service is associated with individual human capital and adjustment costs that would be expected to 
impact negatively on long-term returns to civilian employment. Second, such costs are offset by the fact that, for significant numbers of conscripts, the armed services invested in general skills that were of marketable value in both military and civilian job outlets. Aggregating over a given age cohort of conscripts, the costs are likely to outweigh the benefits but the net costs are probably modest.

(b) The special case of early WWII conscription: 1939 to the start of 1942

There were three important features of conscription during wartime conscription up to 1942 that distinguish it from later years. First, the expected length of war service was over 5 years, well over twice that of later conscription cohorts. Second, for obvious reasons, the scale of conscription in the early war years greatly exceeded that of later callup. Third, and related, the rapid and significant expansion of the armed forces between 1939 and 1942, required conscription from much wider male age bands compared to later years. ${ }^{10}$

So what about the costs and benefits of conscription to the $61 \%$ of wartime conscripts called-up by the end of 1941? To what extent did they differ from the general net costs of conscription discussed above?

Undoubtedly, the costs incurred by a typical WWII conscript during the period 1939-1942 exceeded those of typical later conscript. First, longer service spells among the former undoubtedly translated into more serious losses of civilian work experience and higher transaction costs associated with readjustment back into civilian working life.

\footnotetext{
${ }^{10}$ Recruitment from a wide age spectrum was especially associated with the early war years. Note from Table 2 that by 1943 net changes in the male workforce compared to 1937 were relatively small indicating that the great bulk of recruitment across the $18-35$ age groups occurred during the first half of the war.
} 
Second, the former suffered considerably greater depreciation of human capital than the latter because of higher average pre-conscription work experience - due to call-up of 18 to 35 year olds compared to 18 to 20 year olds.

On the benefit side, both WWII and post-war conscripts experienced general training during their military careers and it is difficult to conclude that one group or another enjoyed a comparative advantage in this respect. ${ }^{11}$ However, wartime conscripts, and especially those called-up in the early war years from a wide age group, enjoyed an important comparative benefit over later conscripts that greatly served to offset their cost disadvantages. By mid 1943 almost 4 million men and over half a million women had joined the armed service, auxiliary services and civil defence. This created severe labour skill shortages. At the same time, as shown in Table 3, male employment in the essential Group 1 and Group 2 industries (see Table 3) either rose modestly or showed slight declines. Yet the wartime demands, especially in metal and chemical industries, required significant employment growth. The most important strategy for tackling labour shortages was to recruit 2.2 million additional women workers into the essential industries. In mid-1939 the proportion of male to female industrial workers was 2.7 to 1 . By mid-1943 it had fallen to 1.6 to 1 (Ministry of Labour and National Service - hereafter MLNS - 1947, p.127). ${ }^{12}$ As can be seen from Table 3,

\footnotetext{
${ }^{11}$ On the one hand, late-war and post-war conscripts enjoyed better job matching than earlier conscripts because the army did not introduce intelligence and aptitude tests until 1942. However, those early WWII conscripts whose military service required the use of general skills - like motor mechanics and carpentry - had a longer and more intensive experience of applying them during their active military service.

${ }^{12}$ Female military conscription - consisting largely of women who joined the Auxiliary Services and Civil Defence - lasted for a much shorter period than men, from 1941 to 1944. It involved about 530,000 women. Women's military call-up commenced in 1941
} 
easily the biggest growth in female wartime employment was within metal industries. ${ }^{13}$

The main expansion of female jobs took place between 1940 and 1943 and covered a vast array of skilled and semi-skilled job tasks ${ }^{14}$ that before military call-up had been dominated by men. Females were able to substitute for males largely due to the process of so-called labour dilution. ${ }^{15}$

Female labour provided employers with a temporary buffer that allowed them to bridge the main production pressures of the war while, at the same time, allowing returning men to regain their pre-war positions in the jobs hierarchy. ${ }^{16}$ This contrasts with the post-war era where young conscripts could be replaced relatively easily by very close

for those aged 20 to 30 , amended to ages 19 to 30 in 1943 . These women could opt to work in specified essential war industries. However, female WWII service was dominated by civilian recruitment into the essential Group 1 metal and chemical industries (Hart, 2008). Female employment growth and increased employment shares in these and certain Group 2 industries are evident from Table 3.

${ }^{13}$ Covering metal manufacture, engineering, motors, aircraft and other vehicles, shipbuilding and ship repair, metal goods manufacture.

${ }^{14}$ See Douie (1950) and ILO (1946) for detailed accounts of the extensive range of job descriptions, both skilled and semi-skilled, filled by women in the metal industries and their quantitative significance within sections of these industries. See also Hart (2009).

${ }^{15}$ Broad production processes, traditionally covered by skilled men with 5-7 years apprenticeships and subsequent on-the-job experience, were broken down into sub processes. This had two consequences for women's employment (Inman, 1957). First, some women were trained for up to 32 weeks to undertake a skilled sub process. Second, the breakdown of processes identified sub-processes that required only semi-skilled labour inputs and so other women trained for shorter periods to fill these.

16 There were efficiency gains to be derived from labour dilution. The identification of semi-skilled job tasks within the previous skilled job descriptions served to reduce unit costs and allow for better matching of skilled workers to skilled job requirements. However, such gains were more confined to the modern, relatively low unionised industries located in the southern regions of Britain. Many employers and unions especially those in the more traditional industries - simply reverted back to earlier process and job task demarcations when the war ended. 
substitute labour since their skill acquisition and on-the-job experience were in their relative infancy.

Four additional reasons account for the largely temporary nature of female-male employment substitution. ${ }^{17}$ First, under the Reinstatement of Civil Employment Act of 1944 men and women who had been called-up for full-time service during WWII were given the right to regain their last pre-conscription jobs. Second, there is evidence that women who were housewives at the start of the war wanted to return to their homes when the war ended. Almost certainly, many of these wanted to start or add-to their families as testified by the large increases in births among 20-29 year old women immediately following the war. Third, since women's rates of pay rose considerably during the war years, many employers cut costs by transferring women holding men's jobs to jobs classified as women's work at about one-third of the hourly rate. Fourth, the largest engineering union, the Amalgamated Engineering Union, had an explicit policy of focusing post-war redundancies on women wartime industrial recruits.

\section{Data}

I begin by reviewing briefly the three data sources on which long term real wage/earnings outcomes are based. All wage and earnings measures are deflated by the British Retail Price Index. The data embrace both full-time and part-time workers with

\footnotetext{
${ }^{17}$ Detailed historical references in respect of points two to four in this paragraph can be found in Smith (1984). Further details on points one to three are given in Hart (2009).
} 
the latter comprising about $2 \%$ of male workers. I exclude observations indicating earnings of less than $£ 1$ per hour or more than $£ 150$ per hour (in 2001 pounds). ${ }^{18}$

\section{New Earnings Survey Panel Data (NESPD)}

The NESPD is a panel covering a random sample of $1 \%$ of the British workforce.

It is an employer survey of individual-level data obtained from company payrolls.

Estimation is based on the data from 1975 to 2001. Data are obtained from company payrolls with employers legally obliged to provide the information which refers to a given week in April of each year. Accordingly, there is a high response rate. Statistics refer, principally, to earnings and hours of work and given they are taken directly from payroll records they are considered to be very accurate. This paper makes use of the basic or standard weekly wage, defined in the NESPD as "gross weekly earnings excluding overtime divided by normal basic hours for employees whose pay for the survey period was not affected by absence". Estimation was also undertaken using hourly wage earnings (including overtime) to replace standard hourly wages but this produced no substantive changes.

\section{General Household Survey (GHS)}

The GHS is a continuous national survey of people living in private households, conducted on an annual basis by the Office for National Statistics (ONS). It started in 1971 and has been carried out since then, except for breaks in 1997-1998 when the

\footnotetext{
${ }^{18}$ The exclusions are similar to those of Card (1999). The numbers involved are relatively very small. In the case of the NESPD, for example, they involve a loss of 75 male observations with wages less than $£ 1$ and 54 males with earnings greater than $£ 150$. The minimum hourly wage was $£ 3.70$ in 2001 .
} 
survey was reviewed and in 1999-2000 when the survey was redeveloped. Unlike NESPD, the GHS is not a panel but rather a set of repeated cross-sections. Being a household survey, it is subject to non-response and reporting error. The average response rate for the GHS during the periods incorporated here is $82 \%$ and it exhibits very little year-to-year variation.

The weekly earnings data in the GHS are probably inferior to NESPD due to misreporting, non-response, and changes over time in the exact definition of earnings. I use the $1972-1978$ GHS surveys to cover males affected by the wartime conscription period and the surveys $1979-1993^{19}$ for the post-war male conscription. The need for this division results from the fact that pre-1979 the GHS survey adopts different earnings measurements than later periods. The earlier period refers to the year preceding the survey rather than, as in the later period, to earnings in the week preceding the interview.

\section{UK Family Expenditure Survey (FES)}

The FES is a voluntary survey of a random sample of private households in the United Kingdom carried out by ONS. It is a survey of household income as well as expenditures on goods and services. The survey started in 1957 with the purpose of providing information on spending patterns in the UK for use in the Retail Price Index. There is about a $60 \%$ response rate. Data are collected throughout the year to cover seasonal variations in expenditures. In addition to expenditure and income data, the FES provides details of the socio-economic characteristics of the households covered,

\footnotetext{
${ }^{19}$ I do not use GHS data from 1994 onwards because (a) that year marks a switch from recording data by calendar to financial year (April to following March), and (b) the survey was not conducted in 1997.
} 
including composition, size, social class, occupation and age of the head of household. I use FES data from 1970 to $1993 .{ }^{20}$ Prior to 1982 , hourly earnings data include overtime hours but these are excluded in later years. To meet this problem, data for $1970-1981$ are used to measure the effects of men's wartime conscription while the post-war period of male conscription is covered by using data from $1982-1993$.

\section{Sample coverage and age ranges}

In general, I show results in respect of data samples covering birth years that are \pm 10 years of the pivotal birth year in respect of conscription dummy. ${ }^{21}$ Thus, estimates of the wage effects of post-war National Service are based on samples of males born between 1933 and 1953; that is 10 years on either side 1943. As for wartime conscription, where I wish to test for differences between early war conscripts and later cohorts, a definitive pivotal age is not so easily defined. From Table 1 we know that $61 \%$ of postings to the armed forces were achieved by the end of 1941 and $79 \%$ by the end of 1942. To be ineligible for conscription in each of these two years males had to be born on or after 1924 or 1925, respectively. In order to test for differences between early wartime and later conscription, I sampled a range of birth years - from 1923 to 1927. Again, I allow for 10 years on either side of each selected pivotal birth year.

\footnotetext{
${ }^{20}$ The start year is 1970 because (a) in 1969 there was a significant reduction in sample size (to about $1 / 8^{\text {th }}$ of other years) with reported mean weekly earnings less than one-half of 1968 and 1970, (b) there is a gap from 1963-68 and (c) there are no available hours data for the earliest years. The end year is 1993 because in 1994 the survey reference period changed from a calendar to a financial-year basis (April to the following March).

${ }^{21}$ Although, see Section 6, where I report on results using different birth cohort ranges.
} 
For my post-war conscription regressions, I use age-ranges of males from 25 to 55. So, for those born in 1943 or later - and therefore not eligible for military call-up the minimum age at which they are observed is 32 . The regressions in respect of WWII use the age range 40 to 60 so as to maximise the number of available observations while avoiding being near to the official retirement age. ${ }^{22}$ So, for example, if an individual born in 1924 is included in the post-war conscription sample (see equation (2) below) then, using NESPD, they would be aged 51 when first observed.

\section{Estimation and Results}

I adopt a regression-discontinuity design (RD) first introduced by Thistlethwaite and Campbell $(1960)^{23}$ to evaluate the real wage effects of the introduction of male and female conscription. I begin by examining the long term earnings effects of post-war conscription, or National Service, and then deal with the special case of WWII.

\section{(a) Post-war National Service}

Post-war conscription was discontinued after December 31 1960, and so those males born after 1943 were not eligible. Accordingly, the regression takes the form

$$
\text { (1) } \ln W_{i}=\alpha_{0}+\alpha_{1} I(Y O B \geq 1943)_{i}+f\left\{Y O B_{i}\right\}+g\left\{A G E_{i}\right\}+\varepsilon_{i}
$$

where $i$ indexes cohort, $W$ is the real hourly wage, YOB is year of birth, $I($.$) is the$ indicator function, $f\left\{Y O B_{i}\right\}$ is a quartic function of year-of-birth, $g\left\{A G E_{i}\right\}$ is a quartic function of age, and $\varepsilon_{\mathrm{i}}$ is an error term.

\footnotetext{
${ }^{22}$ During estimation periods, the official male age of retirement was 65.

${ }^{23}$ Imbens and Lemieux (2008) provide up-to-date developments and discussion.
} 


\section{(b) WWII conscription}

I argued in Section 2(b) that those recruited in the early years of the war, and especially up to the end of 1941, may have experienced different post-war job prospects than later conscripts. Essentially, their pre-war job positions were better protected than later conscripts. If this is the case, then men born in 1924 and later would not be included in this special group. In this case, the RD design is expressed

$$
\text { (2) } \ln W_{i}=\beta_{0}+\beta_{1} l(Y O B \geq 1924)_{t}+f\left\{Y O B_{i}\right\}+g\left\{A G E_{i}\right\}+\varepsilon_{t} \text {. }
$$

Of course, it would be wrong to be dogmatic about what constitutes 'early war' conscripts. The birth years 1923, 1925 and 1926 offer alternatives.

The first column of estimated coefficients in Table 7 shows the effect of ending male military conscription in 1961 - that is $\hat{\alpha}_{1}$ in equation (1). Outcomes are reasonably consistent across data sets and indicate that the withdrawal of conscription is associated with between a $1.5 \%$ and $3 \%$ increase in real wages of the immediate post-conscription age cohorts. Based on NESPD estimates using the baseline specification of a quartic in cohorts, Figure 1 presents the polynomial fits for the pre- and post- 1943 data points. The fitted line is obtained by regressing the wage averages on a birth cohort quartic polynomial and an indicator for the end of adult post-war conscription in respect of the 1943 birth cohort.

The break in 1943 is clear. These estimates are somewhat lower than the earlier findings of Buonanno (2007). ${ }^{24}$

\footnotetext{
${ }^{24}$ The upper estimate in the range shown in Table 7 - that is $3 \%$ - is achieved using GHS. Also using GHS, Buonanno obtains a 5\% higher return among post-conscription male
} 
In Table 7, the NESPD displays the most precisely estimated wage returns. Based on their own work and that of others, Devereux and Hart (2008) compare estimates using the payroll-based NESPD with the GHS and FES household surveys in relation to regression discontinuities estimated in respect of a change in the age of British compulsory school leaving in 1947 . Here too it is very clear that the precision of NESPD is far superior. Since the GHS and FES wage estimates are even less precisely estimated for WWII conscription, I concentrate on my NESPD findings for this earlier period.

Table 8 presents two results in respect of equation (2). They show two significant conscription dummies with the value of 0 for those born up to 10 years before 1924 and 1 for those born during the 10 years thereafter. The second result is based on the same dichotomy around 1925. Those born in 1924 or later could not have started conscription until 1942 at the earliest, while 1943 is the earliest start-date for the second dummy. All other dummies - with break points at 1923, 1926 and 1927 - were insignificantly different from zero. The real earnings of cohorts born in 1924 fell by $2.4 \%$ compared to the preceding cohort. Again using the baseline specification of a quartic in cohorts, Figure 2 presents the polynomial fits for the pre- and post- 1924 data points, with a clear break for the 1924 birth cohort. The 1925 cohort result is also significant but with a dummy variable estimate of roughly half the size of 1924.

Post-war results indicate somewhat modest disadvantages of male age cohorts containing those conscripted into National Service compared to those subsequently

cohorts. His study uses GHS for the period 1983-1998 compared to 1979-1993 used here. I explain in Section 4 why I do not go beyond 1993. 
exempt. As for WWII, the male age cohorts containing those conscripted during the first few years of the war display significantly better labour market returns - though again with reasonably modest differences - compared to the age cohorts that followed.

\section{Robustness Checks}

\section{Birth cohort ranges}

For both post-war and WWII conscription, I experimented with other age cohort intervals - in the range of \pm 3 years to \pm 12 years. The results shown in Tables 7 and Table 8 prove to be remarkably resilient to this exercise: there are no major deviations from these estimates.

\section{Age ranges of wage earners}

Haider and Solon (2006) show that in the U.S. current income is a reasonable proxy for lifetime income for men between their mid-30's and late 40's. To reflect this, I replaced the $25-55$ age band with a $35-50$ band in the post war male regressions. This does not produce significantly different estimates for the conscription dummy compared to the results in Table 7. Data constraints preclude a similar check in relation to the WWII outcomes in Table 8.

\section{Testing for jumps at non-discontinuity points}

I tested for jumps in the two sub-samples on either side of the cut-off value in Figure 1 (ie. post-war conscription), that is where no jumps are expected. Tests were undertaken at the median values of the two sub-samples (see Imbens and Lemieux, 2008, Section 7.3). Estimated standard errors indicated statistically insignificant breaks. This reinforces the finding in respect of post-war conscription. 
Such tests are not helpful in respect of wartime conscription in Figure 2. First, dividing cohorts of women born before 1924 (the cut-off value in Figure 2) by the median leaves small left-side samples. Second, as mentioned in the Section 5, there are indications of significant jumps in 1925. In other words, the classification of who constitutes early war conscripts is not clear-cut.

\section{Schooling}

One possible source of bias in the results is that pre- and post- conscription cohorts may have experienced systematically different lengths of schooling thereby clouding the source of the between-group wage returns. For example, conscription itself may have disrupted the length of education. Using the GHS, I estimated the following equation in respect of post-war National Service:

(3) $S C H_{i}=\gamma_{0}+\gamma_{1} I(Y O B \geq 1943)_{i}+f\left\{Y O B_{i}\right\}+g\left\{A G E_{i}\right\}+\varepsilon_{i}$

where $\mathrm{SCH}$ is age left school. I was also able to substituted SCH with FTE, age when left full-time education, as an alternative dependent variable.

I obtained $\hat{\gamma}_{1}^{\prime}$ s that were always insignificantly different from zero using either SCH or FTE and based on a range of age bands ranging between $1943 \pm 12$ years to 1943 \pm 3 years. For the cohorts affected by equation (3) the minimum school leaving age was 15 years. For WWII conscripts it was 14 years. Unsurprisingly, therefore a similar exercise undertaken for the earlier period also produced no significant schooling effects. 


\section{Women's earnings during male conscription periods}

I estimated the equivalent to the post-war male conscription equation (1) for females with the expectation under the maintained hypothesis of no effect. There were no significant outcomes on the conscription dummy using each of the three data sets. The years during WWII are more complicated because there was both female military and, more importantly, strong elements of female civilian conscription during this period. The WWII female employment picture is analysed in Hart (2009).

\section{Conclusions}

In line with earlier research into the effects of military service, this study finds that British post-war National Service associated with a negative impact on long term real wages earnings of eligible age groups compared to those in adjacent age cohorts to whom military service did not apply. The effect is quite modest, however. Fairly consistently over 3 major data sets and experimenting with age ranges of the relevant cohorts - I estimate that the wage return of conscripts was between $1.5 \%$ and $3 \%$ lower than among the post-conscription birth cohorts. These are expected outcomes because, as discussed in Section 3 (a), while large proportions of conscripts acquired specific training and associated military applications, many others received general training and work experience that were of direct worth in the civilian job market.

In the case of WWII conscription the finding is that those individuals recruited before 1942 - comprising the majority of total wartime conscripts - actually had better long-term earnings outcomes than those age cohorts that followed. Measured about 26 years later, these cohorts enjoyed a $2.4 \%$ real earnings advantage over the cohort that immediately followed them. The main argument advanced in support of this observation 
is that, for the large part, women provided a temporary employment buffer for the military absentees so that men returning from the war did not lose their places in the jobs' hierarchy. This tendency was reinforced by legislation and by government and union sentiments that attempted to give back the serving men's pre-war jobs. 


\section{References}

Angrist, J D. 1990. Lifetime earnings and the Vietnam era draft lottery: evidence from social security administrative records. American Economic Review 80, 313-336.

Angrist, J and A B Krueger. 1994. Why do World War II veterans earn more the nonveterans? Journal of Labor Economics 12, 74-97.

Broad, R. 2006. Conscription in Britain 1939-1964. London: Routledge.

Buonanno, P. 2007. Long-term effects of conscription: lessons from the UK. Mimeo, University of California, Berkeley and University of Bergamo.

Card, D. 1999. The causal effect of education on earnings. Handbook of Labor Economics, Volume 3A, North-Holland.

Douie, V. 1950. Daughters of Britain. Oxford: George Ronald.

Ferguson, T and J Cunnison. 1959. The impact of National Service. British Journal of Sociology 10, 283-290.

Haider, S and G Solon. 2006. Life-cycle variation in the association between current and lifetime earnings. American Economic Review 96, 1278-1296.

Hart, R A. 2009. Did British women achieve long-term economic benefits from working in essential WWII industries? Department of Economics, University of Stirling.

Hart, R A. 2007. Women doing men's work and women doing women's work: female work and pay in British wartime engineering. Explorations in Economic History 44, 114-130.

Hickman, T. 2004. The call up: a history of National Service 1947-1963. London: Headline Book Publishing Ltd.

Howlett, P. 1995. Fighting with figures. London: HMSO. 
Imbens, G and T Lemieux. 2008. Regression discontuity designs: a guide to practice. Journal of Econometrics 142, 615-635.

Imbens, $\mathrm{G}$ and $\mathrm{W}$ van der Klaauw. 1995. Evaluating the cost of conscription in the Netherlands. Journal of Business and Economic Statistics 13, 207-215.

Inman, P. 1957. Labour in the munitions industries. London: Longman, Green and Co.

International Labour Office. 1946. The war and women's employment. The experience of the United Kingdom and the United States. Montreal: ILO.

Knowles, K G J C and D J Robertson. 1951. Earnings in engineering, 1926-1948. Bulletin of the Oxford Institute of Statistics 13, 179-200.

Ministry of Labour and National Service. 1944. Statistics relating to the war effort of the United Kingdom. Command 6564. London: HMSO.

Ministry of Labour and National Service. 1947. Report for the years 1939-1946. Command 7225. London: HMSO.

Parker, H.M.D. 1957. Manpower: a study of war-time policy and administration. London: Longman, Green and Co.

Smith, H.L. 1981. The problem of "equal pay for equal work" in Great Britain during World War II. Journal of Modern History 53, 652-672.

Smith, H.L. 1984. The womanpower problem in Britain during the Second World War. The Historical Journal 27, 925-945.

Thistlethwaite, D.L. and D.T. Campbell. 1960. Regression-discontinuity analysis: an alternative to the ex post facto experiment. Journal of Educational Psychology 51, 309-317. 
Figure 1 Average hourly real basic pay of men aged 25 to 55 by 1933 to 1953 birth cohorts (NESPD)

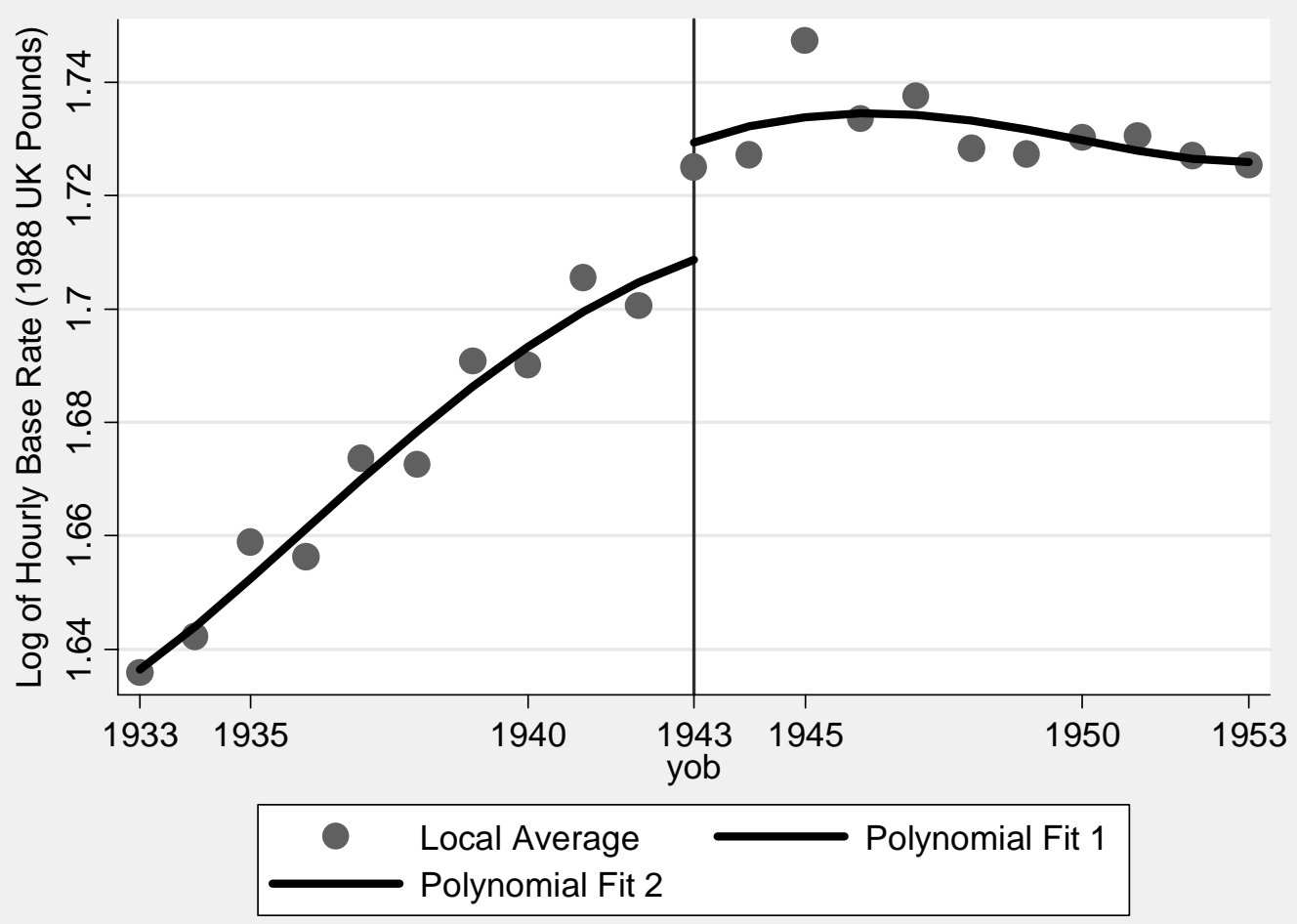


Figure 2 Average hourly real basic pay of men aged 25 to 55 by 1914 to 1934 birth cohorts (NESPD)

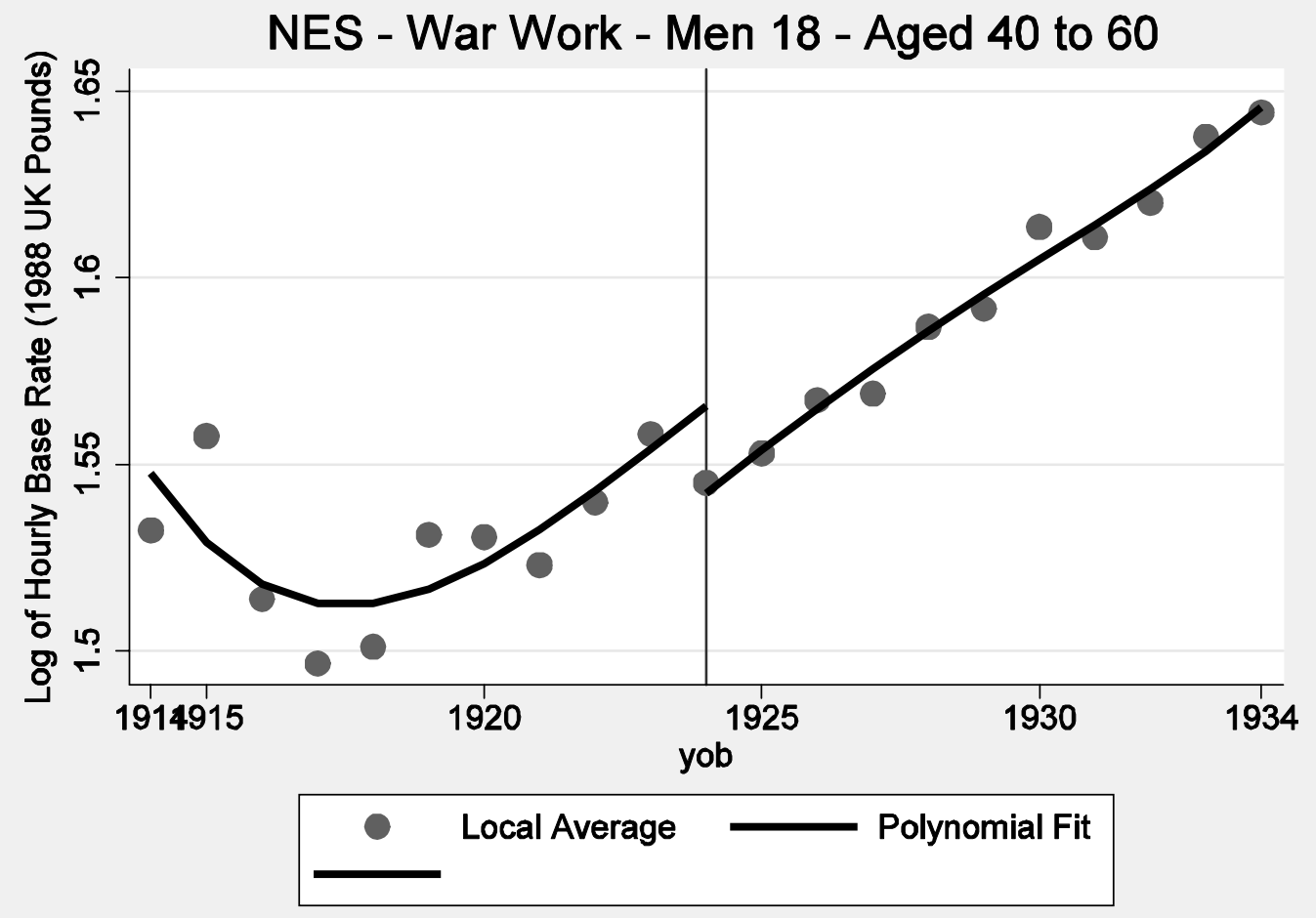


Table 1 Numbers of men registered and posted to armed forces under the National Service Acts, 1939 - 1945

\begin{tabular}{|c|c|c|}
\hline Year & Numbers registered & $\begin{array}{c}\text { Numbers posted to armed } \\
\text { forces }\end{array}$ \\
\hline 1939 & 727 & 177 \\
\hline 1940 & 4100 & 1051 \\
\hline 1941 & 2222 & 604 \\
\hline 1942 & 399 & 513 \\
\hline 1943 & 465 & 319 \\
\hline 1944 & 286 & 217 \\
\hline 1945 (to $30^{\text {th }}$ June) & 156 & 104 \\
\hline Total & 8355 & 2985 \\
\hline
\end{tabular}

Source: Ministry for Labour and National Service [MLNS], 1947, p. 12 and p. 26. 
Table 2 Net changes in the civilian workforce aged 18 to 51: 1942-45 compared to 1937 after adjusting for changes in the birth rates

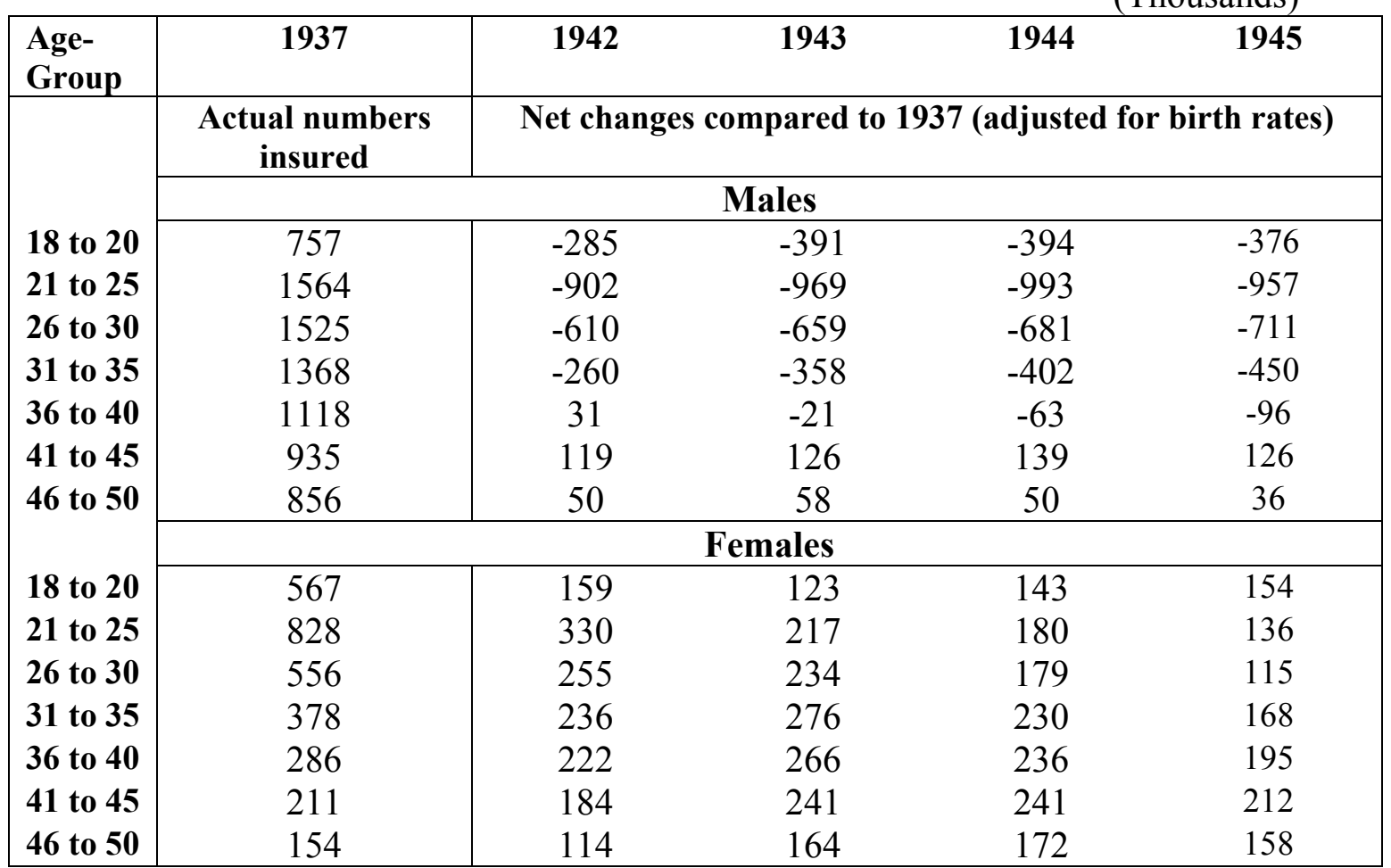

Notes: Figures on insured employees are based on statistics in MLNS, 1947, p. 260. The numbers in the 1942 to 1945 columns are adjusted to account for changes in the birthrates across the age cohorts. For example, there were 757,000 insured males aged 18 to 20 in 1937. These were born between 1917 and 1919. In 1942, there were 560,000 insured males, born between 1922 and 1924 . The number of births between 1922 and 1924 was 1.1168 of those between 1917 and 1919. Therefore, assuming equivalent proportions of insured workers to total births through time, this translates to 845,000 insured workers in 1942 , adjusted for the rise in the birth rate (i.e. $757,000 \times 1.1168$ ). The difference between actual insured numbers and those corrected for the birth rate (i.e. 560,000 - 845,000 = -285,000) represents the estimated drop in the insured employed due to military call-up. Birth statistics for England and Wales are obtained from the Office for National Statistics, Birth Statistics 1937-1983, Birth statistics for Scotland are obtained from General Register Office for Scotland, gro-scotland.gov.uk. 
Table 3 Male and Female Engagement in Armed Forces, Civil Defence and Industry: 1939 - 1946

\begin{tabular}{|c|c|c|c|c|c|c|c|c|}
\hline & \multicolumn{4}{|c|}{ Males aged $14-64$} & \multicolumn{4}{|c|}{ Females aged $14-59$} \\
\hline & June 1939 & June 1943 & June 1945 & Dec. 1946 & June 1939 & June 1943 & June 1945 & Dec. 1946 \\
\hline $\begin{array}{l}\text { Armed forces and auxiliary } \\
\text { services }\end{array}$ & 480 & 4296 & 4653 & 1361 & - & $461(9.7)$ & $437(8.6)$ & $78(5.4)$ \\
\hline Civil defence etc. & 80 & 253 & 112 & 85 & - & $70(21.7)$ & $15(11.8)$ & $4(4.5)$ \\
\hline GROUP 1 & & & & & & & & \\
\hline Metal industries & 2379 & 3025 & 2643 & 2671 & $433(15.4)$ & $1635(35.1)$ & $1257(32.2)$ & $778(22.6)$ \\
\hline Chemical industries & 221 & 280 & 248 & 236 & $73(24.8)$ & $293(51.1)$ & $198(44.4)$ & $117(33.1)$ \\
\hline GROUP 2 & & & & & & & & \\
\hline $\begin{array}{l}\text { Agriculture, horticulture, } \\
\text { fishing, etc. }\end{array}$ & 884 & 879 & 883 & 959 & $66(6.9)$ & $168(16.0)$ & $158(15.2)$ & $122(11.3)$ \\
\hline Mining and quarrying & 868 & 804 & 785 & 790 & $5(0.6)$ & $14(1.7)$ & $14(1.8)$ & $12(1.5)$ \\
\hline National government service & 416 & 515 & 501 & 631 & $123(22.8)$ & $471(47.8)$ & $493(49.6)$ & $385(37.9)$ \\
\hline Local government service & 520 & 342 & 390 & 540 & $326(38.5)$ & $458(57.3)$ & $519(57.1)$ & $485(47.3)$ \\
\hline Gas, water and electricity & 225 & 167 & 165 & 234 & $17(7.0)$ & $33(16.5)$ & $31(15.8)$ & $24(9.3)$ \\
\hline Transport and shipping & 1183 & 979 & 1038 & 1249 & $50(4.1)$ & $197(16.8)$ & $214(17.1)$ & $124(9.0)$ \\
\hline All Group 2 & 4096 & 3686 & 3762 & 4403 & $587(12.5)$ & $1341(26.7)$ & $1429(27.5)$ & $1152(20.7)$ \\
\hline GROUP 3 & & & & & & & & \\
\hline Food, drink and tobacco & 391 & 274 & 276 & 354 & $263(40.2)$ & $245(47.2)$ & $242(46.7)$ & $243(40.7)$ \\
\hline Textiles & 401 & 233 & 222 & 317 & $601(60.0)$ & $436(64.2)$ & $412(65.9)$ & $442(58.2)$ \\
\hline Clothing & 138 & 69 & 70 & 107 & $449(76.5)$ & $312(81.9)$ & $301(81.1)$ & $354(76.8)$ \\
\hline Boots and shoes & 108 & 67 & 66 & 92 & $57(34.5)$ & $45(40.2)$ & $44(40.0)$ & $49(34.8)$ \\
\hline Other manufactures & 917 & 496 & 498 & 807 & $384(29.5)$ & $336(40.4)$ & $343(40.8)$ & $391(32.6)$ \\
\hline Building and civil engineering & 1294 & 700 & 698 & 1235 & $16(1.2)$ & $26(3.6)$ & $24(3.3)$ & $25(2.0)$ \\
\hline Distributive trades & 1888 & 1016 & 978 & 1306 & $999(34.6)$ & $993(49.4)$ & $980(50.1)$ & $998(43.3)$ \\
\hline Other services & 1250 & 576 & 560 & 922 & $975(43.8)$ & $1037(64.3)$ & $1038(65.0)$ & $1044(53.1)$ \\
\hline All Group 3 & 6387 & 3431 & 3368 & 5140 & $3744(37.0)$ & $3430(50.0)$ & $3384(50.1)$ & $3546(40.8)$ \\
\hline
\end{tabular}

Source: MLNS (1947, p. 350). Figures in brackets show percentage shares of female to total employment. The statistics for females count two part-time women as equivalent to one unit. Data include self-employed. 
Table 7 Effect of the abolition of conscription on male log real hourly wage rates: $1943 \pm 10$ years; Males aged 25-55

\begin{tabular}{|l|ccc|}
\hline & NESPD & GHS & FES \\
\hline Conscription dummy & $\begin{array}{c}0.015^{* *} \\
(0.003)\end{array}$ & $\begin{array}{l}0.032^{*} \\
(0.015)\end{array}$ & $\begin{array}{c}0.023 \\
(0.018)\end{array}$ \\
\hline Observations & 789,079 & 18,753 \\
\hline Standard errors in brackets. ** (*) denotes statistically significant at 1\% (5\%) level. \\
Each regression includes both a quartic birth cohort controls and quartic age controls. \\
Male conscription dummy applies to birth cohorts 1933-1953. It is equal to 1 if year $<$ \\
1943 and 1 if year $\geq 1943$. \\
Coverage and construction of wage and earnings data are as follows. NESPD, 1975- \\
2001: wage = [basic weekly wage (excluding overtime)/actual weekly basic hours]. GHS, \\
$\begin{array}{l}\text { 1979-1993: earnings }=\text { [gross weekly earnings/no. of hours usually worked excluding } \\
\text { meals and overtime]. FES, 1982-1993: earnings = [normal gross weekly wage]/usual } \\
\text { weekly hours excluding meals and overtime]. }\end{array}$
\end{tabular}

Table 8 Log real hourly wage effects of WWII conscription on males aged 40 - 60 (NESPD)

\begin{tabular}{|l|c|c|}
\hline Conscription dummy & $\begin{array}{c}\text { YOB } \geq \mathbf{1 9 2 4} \\
(\mathbf{1 9 2 4} \pm \mathbf{1 0} \text { years })\end{array}$ & $\begin{array}{c}\text { YOB } \geq \mathbf{1 9 2 5} \\
\mathbf{( 1 9 2 5} \pm \mathbf{1 0} \text { years })\end{array}$ \\
\hline Observations & $-0.024^{* *}$ & $-0.013^{* *}$ \\
$(0.004)$ & 377,106 \\
\hline Standard errors in brackets. ** denotes statistically significant at 1\% level.
\end{tabular}

